\title{
Investigação de efeitos imediatos de dois exercícios de trato vocal semi-ocluído*****
}

\author{
Investigation of the immediate effects of two semi-ocluded vocal \\ tract exercises
}

\begin{abstract}
Marília Sampaio*
Giselle Oliveira**

Mara Behlau***
\end{abstract}

*Fonoaudióloga. Especializanda em Voz no Centro de Estudos da Voz. Endereço: Rua Edith Mendes G. Abreu, 352 - Apto. 702 - Salvador - BA - CEP 41815-010 (mariliacs@hotmail.com).

**Fonoaudióloga. Doutoranda em Distúrbios da Comunicação Humana da Universidade Estadual Paulista. ViceCoordenadora do Curso de Especialização em Voz do Centro de Estudos da Voz.

***Fonoaudióloga. Doutora em Distúrbios da Comunicação Humana da Universidade Estadual Paulista. Diretora do Centro de Estudos da Voz

****Trabalho Realizado no Centro de Estudos da Voz

Artigo Original de Pesquisa

Artigo Submetido a Avaliação por Pares

Conflito de Interesse: não

Recebido em 02.03.2008

Revisado em 25.08.2008.

Aceito para Publicação em 21.10.2008.

\begin{abstract}
Background: the immediate effects of two semi-ocluded vocal tract exercises. Aim: to verify and compare the immediate effects of the finger kazoo (FK) and phonation with straw exercises (PS). Method: twenty-three women without vocal complaints, aged twenty-three to forty, performed the exercises twice, in a pre-set order (FK - PS - PS - FK), and did a vocal self assessment after each one of these exercises. The sustained [e] vowel and speech (one-ten counting) samples were collected pre and postexercises for the auditory-perceptive evaluation carried out by two trained speech pathologists, and for the acoustic analysis. Results: in the self-assessment, the positive effects (FK $122-77.7 \%$ and PS 118 $-74.7 \%$ ) were more referred than the negative, being mainly mentioned: a clearer (FK $33-21 \%$ and PS $29-18.4 \%$ ), stronger voice (FK $24-15.3 \%$ and PS $26-16.5 \%$ ) and an easier speech (FK $29-18.5 \%$ and PS $30-19 \%)$. In the auditory-perceptive evaluation, a larger number of emissions were considerated better after phonation with straw, as much in the vowel (22-47.8\% post and $19-41.3 \%$ preexercise) as in the speech (24 - 52.2\% post and $15-32.6 \%$ pre) whereas a larger number of emissions were considerate better before the finger kazoo, as much in the vowel (18 - 39.1\% pre and $17-37 \%$ post) as in the speech ( $21-45.6 \%$ pre and $17-37 \%$ post). In the acoustic analysis, it was observed a fundamental frequency decrease after both exercises (FK $6.47 \mathrm{~Hz}$ and PS $5.52 \mathrm{~Hz}$ ). Conclusion: the finger kazoo and phonation with straw exercises produced positive and similar reports in the vocal self-assessment, and similar reports in the acoustic analysis, whereas the auditory-perceptive evaluation indicated positive effects only in the phonation with straw.
\end{abstract}

Key Words: Voice; Voice Training; Speech Acoustics; Speech Production Measurement.

\section{Resumo}

Tema: efeitos imediatos de dois exercícios de trato vocal semi-ocluído. Objetivo: verificar e comparar os efeitos imediatos dos exercícios finger kazoo (FK) e fonação com canudo (FC). Método: vinte e três mulheres sem queixa vocal e idades entre vinte e três e quarenta anos executaram os exercícios duas vezes, em ordem pré-estabelecida (FK - FC - FC - FK), e realizaram uma auto-avaliação vocal após cada um deles. Amostras da vogal sustentada [e] e da fala (contagem um-dez) foram coletadas pré e pós-exercícios, para a avaliação perceptivo-auditiva, realizada por duas fonoaudiólogas treinadas, e para a análise acústica. Resultados: na auto-avaliação os efeitos positivos (FK 122 - 77,7\% e FC 118 - 74,7\%) foram mais relatados que os negativos, sendo os principais: voz mais clara (FK 33 - 21\% e FC 29 - 18,4\%), forte (FK 24 - 15,3\% e FC 26 - 16,5\%) e fala mais fácil (FK 29 - 18,5\% e FC 30 - 19\%). Na avaliação perceptivoauditiva, um maior número de emissões foram consideradas melhores pós-fonação com canudo, tanto na vogal (22 - 47,8\% pós e 19 - 41,3\% pré-exercício), quanto na fala (24 - 52,2\% pós e 15 - 32,6\% pré), enquanto um maior número de emissões foram consideradas melhores pré-finger kazoo, tanto na vogal (18 - 39,1\% pré e 17 - 37\% pós), quanto na fala (21 - 45,6\% pré e 17 - 37\% pós). Na avaliação acústica, foi observada redução da frequiência fundamental após ambos os exercícios (FK 6,47Hz, e FC 5,52Hz). Conclusão: os exercícios finger kazoo e fonação com canudo produziram relatos positivos e semelhantes na auto-avaliação vocal e resultados semelhantes na análise acústica, enquanto a avaliação perceptivoauditiva indicou efeitos positivos apenas na fonação com canudo.

Palavras-Chave: Voz; Treinamento da Voz; Acústica da Fala; Medida da Produção da Fala.

Referenciar este material como:

- Sampaio M, Oliveira G, Behlau M. Investigation of the immediate effects of two semi-ocluded vocal tract exercises (original title: Investigação de efeitos imediatos Z 3 de dois exercícios de trato vocal semi-ocluído). Pró-Fono Revista de Atualização Científica. 2008 out-dez;20(4):261-6. 


\section{Introduction}

Exercises with semi-occluded vocal tract (ESOVT) have been frequently used in the clinical practice aiming to improve vocal economy and efficiency. The partial mouth occlusion during ESOVT produces backward resonance and the expansion of all the vocal tract area, from mouth to larynx, while the glottal activation is kept, tending to steadiness $(1,2)$. Techniques as lip or tongue vibration, bilabial fricatives, labial constriction, prolonged "B" exercise, glottis hardening and tube phonation are considered ESOVT and facilitate source-philter interaction reducing the risks of vibration trauma. These exercises have been suggested in different situations: cases of vocal disorders, subjects with normal voices that whish clearer or sounder voices or to the vocal warmingup (2-5).

Finger kazzo techniques and phonation with straw are ESOVT variations. In both cases there is partial lip occlusion and a certain amount of resistance to the sound production, favoring the perception of the vocal tract and optimizing internal perceptions $(1,2)$.

Several authors studied the effects of ESOVT and reported, for example changes in the fundamental frequency (Fo) and positive changes in subjects with vocal cords mass lesions (2-10). However the effects of these exercises are still slightly known since the focus of the studies have been the use of computerized models and observation only during the performance of the exercises. This way, the aim of the present study is to verify and compare the immediate results of finger kazoo and phonation with straw ESOVT exercises in female subjects without vocal complaints.

\section{Method}

This research has exploratory non-controlled design and was approved by the institution's ethics committee (2613/05). All subjects signed the consent form according to the National Health Council resolution 196/96. Participants were 23 female speechlanguage therapists, ages from 23 to 40 without vocal complaints. Exclusion criteria were: health conditions, use of medicines, smoking or drinking habits. To verify and compare the effects of finger kazoo and phonation with straw exercises vocal selfassessment, acoustic analysis and auditoryperceptual assessment were conducted. Each exercise, with one minute duration, was performed twice by the participants (8) with five minutes intervals (chronometer KENKO, model KK-2808) according to what was indicated by a pilot study, always in the following order: finger kazoo, phonation with straw, phonation with straw and finger kazoo. During the intervals the subjects were asked to proceed to a vocal self-assessment and read a text with habitual production.

To perform the finger kazoo the participants were asked to produce a sounding blow with habitual intensity and frequency and without filling the cheeks, with relaxed and lowered tongue and with the index finger in front of the lips. To perform the phonation with straw, instead of positioning the finger the participant should hold one of the extremities of a straw (of rigid plastic with $8.7 \mathrm{~cm}$ length and $1,5 \mathrm{~mm}$ diameter) with the lips, observing the air flow by the other extremity. The examiner provided a model of both exercises performance.

Vocal self-assessment was registered on a standard protocol containing three questions to be answered by the participants: specific voice changes, post-exercises sensations (multiple choice - Table 1) and general assessment of the effects of the exercises (positive, negative or none).

Samples of the sustained vowel [?] and of speech (counting one to ten) on habitual emission, with the individual sitting on a silent environment were recorded to the auditory-perceptual assessment and acoustic analysis. The recording was realized before and after the exercises with Radio Shack microphone (unidirectional, condenser) placed at $6 \mathrm{~cm}$ and $45 \mathrm{o}$ of the individual's mouth. The samples were recorded directly to the computer(DELLDimension 4600) with the acoustic assessment program Vox Metria (CTS informatica 1.1) and edited in pairs with random order (pre and post-exercise), excluding the initial and final second of each sample to avoid the interference of natural periods of instability. To verify assessment reliability $10 \%$ of the samples were repeated.

The auditory-perceptual assessment was conducted by two speech and language pathologists, voice specialists. The analysis was done individually, with headphones and considered only the samples of the second exercise trials. The examiners could listen to the samples up to three times to conclude the analysis. The instruction was to sign the best sample or the lack of difference between them.

The acoustic analysis used data about the F0 (Hz), the proportion of GNE (Glotal Noise Exitation) and the irregularity of the sustained vowel, besides the speech F0 variability (semitones), considering the first and the second exercise trials. 
Results also had statistical treatment by mean of non-parametric tests. The Wilcoxon test was used on the acoustic analysis to compare the mean and standard deviation (SD) of the values of a same exercise (pre and post performance) and to compare the difference of the results of both exercises. In the auditory-perceptual evaluation and the vocal selfassessment, the general voice assessment item, the Pearson q-square test was used to compare the answers proportions of both exercises. The statistical significance level adopted was 0.05 (5\%).

\section{Resultados}

The vocal self-assessment showed more positive than negative effects similarly on both exercises (Table 1). Specific positive changes were assigned 81 times $(51.6 \%)$ in the finger kazoo and 78 times $(49.5 \%)$ in phonation with straw, whereas negative changes were assigned respectively 10 (6.4\%) times and 11 (6.95) times. The perception of a lower voice was reported after both exercises, with larger occurrence after phonation with straw. About the specific sensations on the voice (Table 1), once again the positive sensations predominated over the negative. They were assigned 41 times (26.1\%) after the finger kazoo and 40 times (25.3\%) after phonation with straw. Negative sensations were assigned 19 times (12\%) after both exercises. In what refers to the general evaluation about the effect of the exercise the perception of voice improvement was larger (finger-kazoo $33-71.7 \%$ and phonation with straw $34-73.9 \%$ ) than the perception of decrease (finger-kazoo 8 - 17.4\% and phonation with straw $5-10.9 \%$ ) or lack of changes (finger kazoo 5- 10.9\% and phonation with straw 7 - $15.2 \%$ ) in both exercises, without statistically significant differences between them on the Pearson test ( $p>0.5)$.

In the auditory-perceptual assessment most of the samples post phonation with straw were chosen as the bests in the sustained vowel as well as in the fluent speech. However, in the finger kazoo the pre-exercise utterances were frequently considered better in the sustained vowel as well as in the fluent speech (Table 2). There were no statistically significant differences between the results in both exercises. It is interesting to mention that the intra-examiner agreement was high, over $80 \%$ in all situations, despite the fact that the interexaminers agreement was just fair, around $54 \%$ in the different tasks.

The acoustic analysis (Table 3) showed a statistically significant reduction of F0 after the finger kazoo exercises $(\mathrm{p}=0.0002)$ and phonation with straw $(\mathrm{p}=0.0001)$ while the other parameters were similar pre and post-exercises. There was no statistically significant difference (Wilcoxon, $\mathrm{p}>0.3$ ) between the results of both exercises on the parameters F0 (mean/SD finger kazoo - 6.47/10.06 and phonation with straw - 5.52/9.65), speech variability (finger kazoo - 0.26/2.30 and phonation with straw - 0.35/2.22), GNE (finger kazoo - 0.02/ 0.10 and phonation with straw $0.01 / 0.10$ ) and irregularity (finger kazoo $0.02 / 0.61$ and phonation with straw 0.04/0.48). 
TABLE 1. Numeric and percentile distribution of answers in vocal self-assessment: sensations and vocal changes aspects.

\begin{tabular}{|c|c|c|c|c|}
\hline \multirow{2}{*}{ Vocal self-assessment } & \multicolumn{2}{|c|}{ finger kazoo } & \multicolumn{2}{|c|}{ phonation with straw } \\
\hline & $\mathrm{N}$ & $\%$ & $\mathrm{~N}$ & $\%$ \\
\hline \multicolumn{5}{|l|}{ Vocal changes } \\
\hline \multicolumn{5}{|l|}{ Positives } \\
\hline Stronger & 24 & 15.3 & 26 & 16.5 \\
\hline Clearer & 33 & 21 & 29 & 18.4 \\
\hline Easier & 24 & 15.3 & 23 & 14.6 \\
\hline \multicolumn{5}{|l|}{ Negatives } \\
\hline More difficult & 2 & 1.3 & 3 & 1.9 \\
\hline Weaker & 2 & 1.3 & 4 & 2.5 \\
\hline Dirtier & 6 & 3.8 & 4 & 2.5 \\
\hline \multicolumn{5}{|l|}{ Pitch } \\
\hline Lower & 4 & 2.5 & 7 & 4.4 \\
\hline Higher & 2 & 1.3 & 3 & 1.9 \\
\hline \multicolumn{5}{|l|}{ Sensations } \\
\hline \multicolumn{5}{|l|}{ Positives } \\
\hline Easier speech & 29 & 18.5 & 30 & 19 \\
\hline More loose muscles & 12 & 7.6 & 8 & 5.0 \\
\hline Steadier voice & 0 & - & 2 & 1.3 \\
\hline \multicolumn{5}{|l|}{ Negatives } \\
\hline Dry mouth or throat & 7 & 4.5 & 10 & 6.3 \\
\hline Tiredness & 11 & 7.0 & 9 & 5.7 \\
\hline Noise in the voice & 1 & 0.6 & 0 & - \\
\hline Total & 157 & 100 & 158 & 100 \\
\hline
\end{tabular}


TABLE 2. Frequency of the answers to the auditory-perceptual assessment referring to the better vowel emission and speech pré and post exercises.

\begin{tabular}{|c|c|c|c|c|c|}
\hline \multirow[t]{2}{*}{ Moment } & \multicolumn{2}{|c|}{ finger kazoo } & \multicolumn{2}{|c|}{$\begin{array}{c}\text { Phonation with } \\
\text { straw }\end{array}$} & \multirow{2}{*}{$\begin{array}{c}\text { p- } \\
\text { value }\end{array}$} \\
\hline & $\mathrm{n}$ & $\%$ & $\mathrm{n}$ & $\%$ & \\
\hline \multicolumn{6}{|l|}{ Vowel } \\
\hline Pre better & 18 & 39.1 & 19 & 41.3 & \\
\hline Post better & 17 & 37.0 & 22 & 47.8 & 0.2325 \\
\hline Equal & 11 & 23.9 & 5 & 10.9 & \\
\hline Total & 46 & 100 & 46 & 100 & \\
\hline \multicolumn{6}{|l|}{ Speech } \\
\hline Pre better & 21 & 45.6 & 15 & 32.6 & \\
\hline Post better & 17 & 37.0 & 24 & 52.2 & 0.3227 \\
\hline Equal & 8 & 17.4 & 7 & 15.2 & \\
\hline Total & 46 & 100 & 46 & 100 & \\
\hline
\end{tabular}

TABLE 3. Mean and standard deviation of the acoustic parameters pre and post exercises.

\begin{tabular}{|c|c|c|c|c|c|}
\hline \multirow{2}{*}{ Parameters } & \multicolumn{2}{|c|}{ Pre } & \multicolumn{2}{|c|}{ Post } & \multirow{2}{*}{ p-value } \\
\hline & Mean & SD & Mean & SD & \\
\hline \multicolumn{6}{|l|}{ Finger Kazoo } \\
\hline $\mathrm{F}_{0}$ Vowel $(\mathrm{Hz})$ & 196.95 & 21.71 & 190.49 & 20.22 & 0.0002 \\
\hline $\begin{array}{l}\text { Speech } \\
\text { variability(ST) }\end{array}$ & 6.13 & 2.03 & 5.87 & 1.72 & 0.5262 \\
\hline GNE & 0.88 & 0.09 & 0.86 & 0.12 & 0.5081 \\
\hline Irregularity & 2.91 & 0.43 & 2.93 & 0.68 & 0.3786 \\
\hline \multicolumn{6}{|c|}{ Phonation with straw } \\
\hline $\mathrm{F}_{0} \operatorname{Vowel}(\mathrm{Hz})$ & 197.59 & 19.68 & 192.07 & 20.01 & 0.0001 \\
\hline $\begin{array}{l}\text { Speech } \\
\text { variability(ST) }\end{array}$ & 6.15 & 1.80 & 5.80 & 2.03 & 0.2524 \\
\hline GNE & 0.89 & 0.12 & 0.91 & 0.07 & 0.7655 \\
\hline Irregularity & 2.96 & 0.62 & 3.00 & 0.57 & 0.5442 \\
\hline
\end{tabular}

$\mathrm{SD}=$ standard deviation; $\mathrm{F}_{0}=$ Fundamental frequency; $\mathrm{Hz}=$ Hertz; $\mathrm{ST}=$ semitones;

$\mathrm{GNE}=$ Glottal to Noise Exitation Ratio.

*Wilcoxon 


\section{Discussão}

The adjustments allowed by the ESOVT are varied and very interesting. The partial lip occlusion produces the sensation of a slight resistance to the air flow facilitating the exercise control and performance without overstressing the glottis (2). The vocal tract constriction alters the balance of internal and atmospheric pressure, modifying the glottal and vocal tract configuration and producing different acoustic patterns. The intra-oral pressure increase results in adduction and abduction forces of the vocal folds(9), reducing the tension and the collision impacts over the vocal folds (5).

In the present study, the observed results in the vocal self-assessment suggest more comfort during phonation, probably due to the changes in the vibratory patterns of the vocal folds and to the reduction in the first formant and in the sub-glottal pressure necessary to phonation (Table 1). The resulting sensorial effects should be the reduction of the phonation pressure, of the glottal flow and, at the same time, a voice that is harmonically rich (10). That is the idea of the lip constriction and vocal tract lengthening exercises (4). It is expected that the subject may be able to perceive the economic vocal production and to use it in the habitual speech or singing, that is, in vocal production situations that are different from the exercise situation. The finger kazoo and the phonation with straw could be included in vocal warming programs, for example $(2,4,5)$. The partial lip occlusion and vocal tract lengthening could be used during practices of emphasis and intonation (2). It should be emphasized that the participants profession may have facilitated the perception of the vocal changes and influenced the self assessment results. Future studies comparing self assessment of speech-language pathologists and other professionals should provide more data about the perception of vocal changes.

The auditory-perceptual assessment indicated improvement of the auditory impression only in the phonation with straw (Table 2). The results observed in the finger kazoo were similar to those of another study with glottal hardening (8). The author (8) found a larger number of emissions considered better before the exercise in the group of women without vocal folds lesions, emphasizing the association between the motor adjustments produced by glottal hardening and the resulting auditory perception. Some factors may have favored the effects of the phonation with straw over the auditory perceptual assessment in the present study: the lengthening of the vocal tract provided by the straw, for example, or the area of lip occlusion and the resistance to the air flow, more easily controlled in the phonation with straw than in the finger kazoo. Other hypothesis is that the time of execution of the finger kazoo was not sufficient to present more evident results in women without complains. However, the auditory-perceptual assessment and the time variable have not been the focus of the studies about the subject $(2,3,5-7,10)$. New studies comparing the effects of the exercises depending on the execution time may clarify these issues.

In what refers to the inter-examiner agreement, observed on the auditory perceptual assessment (Table 2), it should be considered that the task of analyzing the voices of individuals without complaints is harder than to compare the effects of exercises in dysphonic individuals. Besides, the auditory analysis did not asked for a characterization of specific parameters, but only the indication of the best emission, what may be related to different aspects for each examiner. A new evaluation considering specific parameters may aide the understanding of aspects involved in the results.

About the acoustic analysis (Table 3), most of the parameters varied discreetly and nonsignificantly, probably because the voices did not have any disorder (11). Studies about dysphonic voices and the analysis of the delayed effect of exercises may indicate more evident changes in the chosen acoustic parameters. The F0 reduction in both exercises may be related to the tension reduction $(5$, 11), to the vocal tract adjustments and to reactance (Table 3). The reactance is part of the resistance to the vocal production that is called impedance and allows saving the acoustic energy. This energy changes the glottal flow and the oscillatory characteristics of the vocal folds $(2,7,10)$. The study of impedance represents an important step to understanding the benefits of the ESOVT. Story, Laukkanen, Titze (10) studied the effects of constriction, vocal tract lengthening and acoustic impedance in seven computerized configurations of the vocal tract and observed larger increase of the impedance and F0 lowering in the configuration corresponding to the phonation with straw in comparisson with the bilabial fricative configuration. Bickley, Stevens (6) studied the interactions between vocal tract configuration and vocal folds vibration of six individuals with the electro-glottal analysis during the emission of consonants and the phonation with tubes of different diameters. Data showed the increase during the open phase in sounds with more lip constriction, as the $/ \mathrm{v} /$, and in phonation with tubes, besides the $\mathrm{F} 0$ reduction of the first formant, 
reduction of sub-glottal pressure and changes in vocal folds vibration pattern.

The results found can be useful to understand the effects of the finger kazoo and the phonation with straw, and point out to its application in different situations.

\section{Conclusion}

The finger kazoo and phonation with straw exercises generated positive and similar results, verified in the vocal self-assessment, which indicated greater phonation comfort. In the acoustic analysis there is a decrease in F0 after the performance of both exercises. The auditoryperceptual assessment indicated after-exercise evident improvement only after the phonation with straw.

\section{References}

1. Behlau M. Voz - o livro do especialista. 1a ed. Vol 2. Rio de Janeiro: Revinter; 2005. p. 474-77

2. Titze I. Voice training and therapy with a semi-occluded vocal tract: rational and scientific underpinnings. J Speech Lang Rear Res. 2006;49:448-59.

3. Elliot N, Sundberg J, Gramming P. Physiological aspects of a vocal exercise. J Voice. 1997;11(2):171-7.

4. Bele IV. Artificially lengthened and constricted vocal tract in vocal training methods. Logoped Phoniatr Vocol. $2005 ; 30(1): 34-40$

5. Titze I, Finnegan E, Laukkanen A, Jaiswal S. Raising lung pressure and pitch in vocal warm-ups: the use of flow resistant straws. J Singing. 2002;58(4):329-38.

6. Bickley CA, Stevens KN. Effects of a vocal tract constriction on the glottal source: data from voiced consonants. In: Baer, Sasaki, Harris. Laryngeal function on phonation and respiration. San Diego: College hill press, 1987. p. $239-53$.
7. Hanamitsu M, Kataoka H. Effect of Artificially Lenghtened Vocal Tract on Vocal Fold Oscillation's Fundamental Frequency. J Voice. 2004;18(2):169-75.

8. Nascimento CM. Análises perceptivo-auditiva, acústica e da configuração laríngea de indivíduos com voz adaptada e disfônica pré e pós aplicação da técnica de firmeza glótica [dissertação]. São Paulo: Universidade Federal de São Paulo - Escola Paulista de Medicina; 2005.

9. Stevens K. Vocal-fold vibration for obstruent consonants. In: Gauffin, Hammaberg. Vocal fold phisiology: acoustic, perceptual and physiological aspects of voice mechanisms. San Diego: Singular; 1991. p. 29-36.

10. Story B, Laukkanen A, Titze I. Acoustic impedance of an articicially lengthened and constricted vocal tract. J Voice. 2000;14(4):455-69.

11. Behlau M. Voz - O Livro do Especialista. vol 1. Rio de Janeiro: Revinter; 2001. p. 133-47. 